\title{
The dog as a sentinel species for environmental effects on human fertility
}

\author{
Rebecca Nicole Sumner ${ }^{1, *}$, Imogen Thea Harris ${ }^{1, *}$, Morne Van der Mescht ${ }^{2}$, Andrew Byers ${ }^{2}$, \\ Gary Crane William England ${ }^{2}$ and Richard Graham Lea ${ }^{2}$ \\ ${ }^{1}$ Hartpury Equine, Hartpury University and Hartpury College, Gloucestershire, UK and ${ }^{2}$ School of Veterinary \\ Medicine and Science, The University of Nottingham, Leicestershire, UK
}

Correspondence should be addressed to R N Sumner; Email: Rebecca.Sumner@hartpury.ac.uk

*(R N Sumner and I T Harris contributed equally to this work)

\begin{abstract}
Despite the vast body of evidence that environmental toxicants adversely affect reproductive development and function across species, demonstrating true cause and effect in the human remains a challenge. Human meta-analytical data, showing a temporal decline in male sperm quality, are paralleled by a single laboratory study showing a similar 26-year decline in the dog, which shares the same environment. These data are indicative of a common cause. Environmental chemicals (ECs) detected in reproductive tissues and fluids induce similar, short term, adverse effects on human and dog sperm. Both pre- and post-natal stages of early life development are sensitive to chemical exposures and such changes could potentially cause long term effects in the adult. The environmental 'pollutome' (mixtures of ECs) is determined by industrialisation, atmospheric deposition and bioaccumulation and characterises real-life exposure. In Arctic ecosystems, dietary and non-dietary chemical contaminants are detectable in biological tissues and linked with adverse health effects in both dogs and their handlers. In the female, such exposure could contribute to disorders such as ovarian insufficiency, dysregulated follicle development, ovarian cancer, and polycystic ovarian syndrome. In the dog, ovarian chemical concentrations are greater in the testis. In addition, preliminary studies indicate that dietary exposures may influence the sex ratio in the offspring in favour of females. Within this article, we review current knowledge on chemical effects on human reproduction and suggest that the dog, as a sentinel species for such effects, is an essential tool for addressing critical data gaps in this field.
\end{abstract}

Reproduction (2020) 159 R265-R276

\section{Sentinels: a historical perspective}

In the early twentieth century, coal miners exploited the enhanced sensitivity of the canary as an early warning system to carbon monoxide. As soon as the canary birds fell off their perch, miners had time to respond to ensure their own safety (reviewed Burton 2014). This highly cited example of the use of an animal as a bio-monitor illustrates the utility of a sentinel species for assessing risk to human well-being when exposed to environmental hazards (Bowser \& Anderson 2018). Since the use of canaries in coal mines, a range of other species have been proposed as sentinels for infectious agents, food hazards, or toxic substances present in the immediate environment (Rabinowitz et al. 2010). Some key examples of these are outlined in Table 1.

While not demonstrating true cause and effect, sentinel species have been used as an index of environmental pollution in soil, air, plants, water, and human habitats. For example, the common earthworm can provide information on the detritus in the soil in addition to the dietary exposure of birds that prey on such species. Another example is that of sheep, providing an index of the exposure from plant material ingested throughout grazing and any soil swallowed in the process. In the aquatic world, sentinel species include oysters, fish, and animals that obtain their food from the aquatic environment, such as seals, dolphins, and killer whales. With respect to the latter, bioaccumulation of PCBs through the food chain has been associated with a decline in species number, placing the highly contaminated killer whale at a high risk of population collapse (Desforges et al. 2018) and eliciting severe health consequences (Haraguchi et al. 2006, Alava \& Gobas 2016, Kurt-Karakus et al. 2019).

In the human household, dogs and cats share our environment more than any other species and are exposed to household contaminants similar to that of humans. In the Western world, dogs tend to live and travel with their owners and are thus exposed to not only the same infectious agents, but also to non-infectious environmental factors, such as chemical pollutants, of 
Table 1 Animal models proposed as sentinel models for the study of environmental exposure to endocrine disrupting chemicals.

\begin{tabular}{|c|c|c|c|}
\hline Proposed model & Specific area of study & Evidence & Reference \\
\hline \multicolumn{4}{|l|}{ Companion animals } \\
\hline Feline & Low-level chronic exposure to PBDEs & Empirical & Dye et al. (2007) \\
\hline \multirow[t]{3}{*}{ Canine } & & Empirical & $\begin{array}{l}\text { Schilling et al. (1988), López-Alonso et al. (2007), } \\
\text { Sonne et al. (2010, 2020), Lea et al. (2016b) }\end{array}$ \\
\hline & Metal concentration in tissue & & \\
\hline & Exposure of chemicals within environment & & \\
\hline Canine/feline & $2,3,7,8$ Tetrachlorodibenzodioxin & Empirical & Schilling \& Stehr-Green (1987) \\
\hline \multicolumn{4}{|l|}{ Production animals } \\
\hline \multirow[t]{3}{*}{ Bovine/ovine } & & Empirical & $\begin{array}{l}\text { Wahl \& Reif (2009), Petro et al. (2010), } \\
\text { Lea et al. (2016a) }\end{array}$ \\
\hline & Sperm quality & & \\
\hline & $\begin{array}{l}\text { Tissue and fluid concentrations } \\
\text { of PCB, OCPs, and PBDEs }\end{array}$ & & \\
\hline \multicolumn{4}{|l|}{ Wildlife species } \\
\hline \multirow[t]{3}{*}{ Primate } & & Empirical & Mitchell et al. (2008) \\
\hline & Germ cell differentiation & & \\
\hline & Testicular germ cell tumour & & \\
\hline Mink & Mercury and PCBs & Review & Basu et al. (2007) \\
\hline Marine mammals & Anthropogenic toxins & $\begin{array}{l}\text { Case Study } \\
\text { and review }\end{array}$ & $\begin{array}{l}\text { Bossart (2006), Sonne (2010), } \\
\text { Jepson et al. (2016), Sonne et al. (2019) }\end{array}$ \\
\hline \multicolumn{4}{|l|}{ General reports } \\
\hline Domestic animals & Endocrine disruptors & Review & Majdič (2010) \\
\hline Mammals & Toxic environmental contaminants & Review & O'Brien et al. (1993) \\
\hline Animals & ECs & Review & Van Der Schalie et al. (1999) \\
\hline \multirow[t]{3}{*}{ Companion animals } & & Review & Schmidt (2009) \\
\hline & Public health & & \\
\hline & Environmental contaminants & & \\
\hline
\end{tabular}

ECs, Environmental chemicals; OCPs, Organochlorine pesticides; PBDEs, Polybrominated diphenyl ethers; PCBs, Polychlorinated biphenyls.

household or recreational origin. It follows therefore that environmentally linked health conditions in the dog may be mirrored in the owners. Sentinel species typically provide a range of tissues for chemical analysis post-slaughter. In contrast, the routine surgical neutering of hundreds of thousands of dogs and cats provides easy access to surplus reproductive tissues which could be used for this purpose. Furthermore, after routine neutering, the male reproductive tract can be further utilised to provide sperm from the tail of the epididymis (Ponglowhapan et al. 2006). Another method by which the dog may be used as a sentinel is through the provision of sperm as part of routine fertility monitoring. This is a procedure tolerated by many species (Hermansson \& Forsberg 2006) and provides a further, cost effective, resource for monitoring contaminants and the quality of the ejaculate. For these reasons, our recent work has focussed on the domestic dog as an index of the reproductive health of humans, particularly as it shares the same environment.

\section{Temporal trends in human reproductive and metabolic health}

In humans, perturbed reproductive potential is characterised by reports of declining semen quality over several decades, an increase in incidence of testicular cancer, malformations of male babies at birth, precocious female puberty, premature menopause, and ovarian cancer. These temporal changes are not limited to reproductive parameters, since a striking increase in global obesity, other cancers, and metabolic syndrome have occurred over the same period (Borch-Johnsen 2007).

Although the precise drivers behind these temporal trends remain uncertain, ECs have been implicated as playing a role alongside Westernised lifestyles and geneenvironment interactions (Ellulu \& Jalambo 2017). In support of this hypothesis, many chemicals have been described as endocrine disrupting, obesogens, and metabolic disrupting, raising considerable concern over their effects on animal and human health (Landrigan et al. 2018).

\section{Male semen quality and testicular dysgenesis syndrome}

There is an increasing body of published evidence to indicate that human male fertility and/or reproductive health has declined over the last 40 to 60 years (Levine et al. 2017). Meta-analytical studies suggest an approximate $50 \%$ decline in sperm concentration over the past 70 years, averaging a $2 \%$ decline per annum (Carlsen et al. 1992, Swan et al. 2000, Levine et al. 2017). Alarmingly, this rate of decline appears to show no 'levelling off' in more recent years and an increasing proportion of men with less than 40 million sperm per $\mathrm{mL}$ of ejaculate has been reported (Sharpe 2012). 
Other parameters of sperm function, such as motility and morphology, have been less extensively reported. There are reports indicative of a decline in percentage morphologically normal sperm along with a decline in sperm count over a 17-year period limited to France (1989-2005) (Rolland et al. 2013). More recently, two separate studies have reported a temporal decline in total motile sperm count at fertility centres in Europe and North America from 2002 to 2017 (Chang et al. 2018, Tiegs et al. 2019). Such adverse temporal trends have been linked with additional temporal global increases in reproductive perturbations, such as testicular cancer (TCa), and genitourinary abnormalities, such as cryptorchidism and hypospadias.

Collectively, the adverse reproductive trends present today are termed testicular dysgenesis syndrome (TDS) (Skakkebaek et al. 2016). Over a 10-year period, the global total incidence rate of TCa has increased by $5.6 \%$, with higher incidences in developed vs undeveloped countries (Park et al. 2018). Similarly, subtypes of $\mathrm{TCa}$, including seminoma and nonseminomas, increased annually by $3.26 \%$ and $1.15 \%$, respectively, with significant variation between racial and ethnic populations (Ghazarian et al. 2018). TCa incidence appears to have increased incidence at a younger age, adding further evidence of a possible environmental aetiology (Pishgar et al. 2019).

\section{The human sperm quality debate}

Adverse temporal trends in male sperm quality have raised much controversy ever since the concept was first proposed by Carlsen et al. (1992) (Pacey 2013). This is predominantly a result of limitations in the heterogeneity of meta-analytical publications, in addition to the inclusion of historical data sets (Carlsen et al. 1992, Swan et al. 2000). Developments in semen analysis have led to a shift towards the use of haemocytometer techniques as opposed to the Makler Chamber. Indeed, when applying modern technologies with increased precision, sperm count values have been reported to be 1.5-2.7 times lower, thus giving the impression of a decline in sperm quality (Pacey 2013). In subsequent studies, the exclusion of those that did not use a haemocytometer and the utilisation of standardised PRISMA and MOOSE meta-analytical protocols still continued to show a decline in fertility (Levine et al. 2017). Furthermore, a decline in total motile sperm count between 2002 and 2017 has recently been reported. This was based on the analysis of data generated from just two laboratories (Tiegs et al. 2019).

\section{The dog as a sentinel for human environmental chemical exposure}

The dog lives in close proximity to humans, where individuals are exposed to similar environmental factors. Parallel temporal trends of semen quality have been reported in the dog sentinel model, with an overall decline of $30 \%$ in progressive sperm motility over a period of 26 years (Lea et al. 2016b). In contrast to the human meta-analyses, the dog study used semen quality parameters collated from a single laboratory by staff with standardised training, promoting consistent analytical methodologies. Consequently, the confounders that complicate the interpretation of meta-analytical studies in the human do not apply and this in turn adds to the weight of evidence for a decline in semen quality in both species.

Genetic, epigenetic, or lifestyle influences on these reproductive trends cannot be ruled out, particularly with respect to the many potential confounders that account for the noise in the human studies. In addition to changing methodologies, tight underwear has been linked with poor sperm quality and other factors such as smoking, alcohol, physical activity, adiposity, and cell phone usage have also been suggested as possible factors (Mínguez-Alarcón et al. 2018, Kaya et al. 2020). In the dog study, the list of possible alternative causes for declining sperm quality is smaller, mostly due to the 'non meta-analytical approach' used. In addition, within the population of stud dogs studied, heritability measures for a range of sperm quality parameters, including reduced motility, were low (England et al. 2010). Given that there was no influence of breed, body weight, or sire, an environmental aetiology would appear to be the most likely cause.

Over the same period as the adverse trends in dog sperm motility, an increased incidence rate of cryptorchidism in male pups was observed from the same population of stud dogs (Lea et al. 2016b). Preliminary evidence suggests that the incidence of testicular tumours in the dog has increased over a 40-year period and that the histological characterisation of such tumours is similar to that reported in the human (Grieco et al. 2008a). In total, these studies suggest that the dog exhibits the same range of reproductive abnormalities as reported in the human (Grieco et al. 2008b, Ghazarian et al. 2018). Such trends demonstrate the importance and worth of the dog as a sentinel species for environmental influences on human reproductive health. However, in contrast to the 'canary in the coalmine scenario', the mechanism underlying these reproductive temporal trends remains uncertain. Although we cannot be certain of a common trigger in both species, there is a clear commonality in the temporal reproductive trends observed and thus the proposal is that the underlying aetiology is environmental and consistent in both the dog and human.

\section{The environmental 'pollutome'}

Despite the ongoing debate surrounding reproductive perturbations, the weight of evidence suggests a common 
aetiology involving the interaction of a complex group of anthropogenic ECs (Bellingham et al. 2009, CabreraRodríguez et al. 2019, Sumner et al. 2019). There exist more than 14,000 classified environmental pollutants inclusive of, but not limited to, organic chemicals, heavy metal ions, and trace elements (Jeon et al. 2015, Daoud et al. 2017, Dusanov et al. 2018). A multitude of in vitro studies have sought to investigate the pathogenesis and mechanisms by which ECs disrupt endocrine and metabolic functionality, resulting in a number of reproductive and non-reproductive perturbations. However, such research is limited in its extrapolation to the human population due to the complexity of chemical mixtures involved in real-life exposure. This further emphasises the importance of alternative models including the utilisation of a sentinel species.

Organic ECs are typically utilised for industrial and agricultural processes due to their properties as plasticisers, pesticides, and solvents (Chen et al. 2019). Dependent on the congener, ECs are present in a variety of industrialised resources (Fig. 1). ECs are released into the environment either through direct emission from the production process or migration from products themselves (Wania 2003). The latter is possible due to the inability of many ECs to chemically bond to the matrices in which they originate, leaching into the surrounding environment (Lenoir et al. 2016). Present in air, water, soil, and vegetation, ECs are consistently available for uptake by humans and other species on a global scale (Terzaghi et al. 2018). In reference to the agricultural industry, the use of EC contaminated sewage sludge for pasture fertilisation and organochlorine pesticides is a primary concern due to studies demonstrating detectable levels of repro-toxic ECs including phthalates and Bisphenol-A (BPA) (Rivera et al. 2009, Tran et al. 2015).

Industry plays a major role in global pollution. The global distribution of chemicals facilitates the spread and atmospheric deposition of ECs in remote nonindustrialised areas of the world, thus EC contamination is ubiquitous. This is particularly true for persistent organic pollutants (POPs) - ECs including PCBs, PBDEs, organochlorine pesticides and dioxins - that are categorised by extended half-lives and high lipophilicity, making them bio-persistent in nature (Wania 2003). Numerous chemical congeners have thus been detected in a range of biota and in ecosystems in areas once considered isolated from anthropogenic influence including ant cuticles from the deep Amazonian rain forest; Amazonian caymen and fish; polar zones including the Arctic ecosystems; and endemic arthropods in the Mariana and Kermadec trenches, the two deepest oceanic trenches (Wania 2003, Lenoir et al. 2016, Jamieson et al. 2017). Shockingly, EC levels have also been detected in Arctic ecosystems. In coastal areas, the Arctic fox has been identified as a sentinel for contaminant monitoring in humans, particularly in relation to the element mercury from a marine diet. In addition, sled dogs living with their handlers have been identified as sentinels to both dietary and non-dietary environmental contaminants (Harley et al. 2016). The concept of the sled dog as a sentinel model to monitor arctic ecosystems has recently been highlighted by Sonne and colleagues (Sonne et al. 2020).

Marine ecosystems are the final destination for many persistent ECs. Aquatic species are thus exposed to ECs and these tend to accumulate within the adipose tissue (Jeong et al. 2019). Elevated bodily burdens of lipophilic chemicals have been found to increase at each trophic level, resulting in bio-magnification in species with higher blubber content and longer life spans, such as apex predators. Consequently, such apex predators are of great scientific interest for further understanding the effect of chronic EC exposure and substantial levels of contamination. An interesting comparison is that of three aquatic species displaying high blubber content with differing diets, from the herbivorous Dugong dugon (otherwise known as the sea cow), to the finless porpoise (surviving mainly on a fish based diet), and finally the killer whale (with a main dietary source of contaminated seal blubber). The Dugong dugon has reported bodily burdens of PBDE of approximately $120 \mathrm{ng} / \mathrm{g}$ lipid weight (Iw) (Weijs et al. 2019). In Korean coastal line populations, the finless porpoise, an endangered marine mammalian species, is reported to have PBDE concentrations at around $294 \mathrm{ng} / \mathrm{g}$ Iw (Jeong et al.

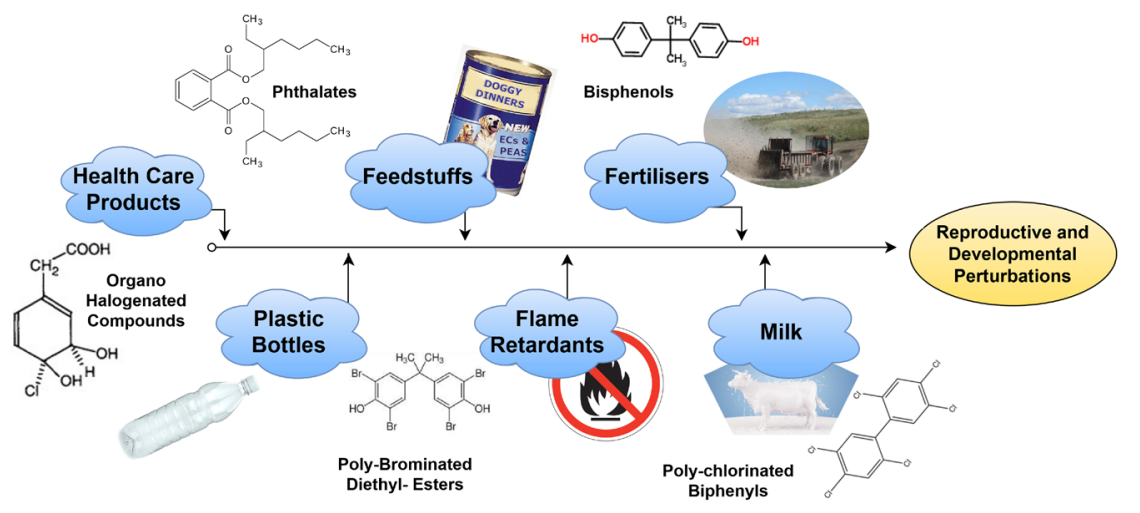

Figure 1 Overview of sources giving rise to environmental chemicals. This figure illustrates sources in which chemicals present within the environmental 'pollutome' could potentially contribute to reproductive and developmental perturbations. 
2019). In the male southern Pacific resident killer whale, PBDE levels are reportedly eight times greater than that of the Dugong dugon (Rayne et al. 2004). Although geographical variation in the environmental 'pollutome' of each habitat will vary, higher concentrations in killer whale populations are likely due to the consumption of contaminated seal blubber leading to the biomagnification of these lipophilic ECs. The reported concentrations in each of these species demonstrate the ability of ECs to bio-magnify at each trophic level, but also highlight exposure routes other than the consumption of contaminated meat, raising additional concern of reproductive health in herbivorous species. Given that the three species discussed are endangered populations, concerns of further population decline due to the repro-toxic nature of ECs have been raised.

Due to EC congeners being utilised for specific industrial or agricultural purposes, it follows that the profile of contaminants constituting the 'pollutome' could reflect this variation (Fig. 1). To our knowledge, present research is restricted to geographical variation in EC levels, with limited understanding of contaminant profiles in relation to specific industry processes. Assessing ecotoxicological risks associated with exposure to a multitude of ECs are essential due to their synergistic toxicity (Jeong et al. 2019). To asses industrially associated contaminants, ants have been proposed as a valuable bio-monitoring species for environmental contamination and the chemical profiling of differing geographical regions due to the abundance of ant populations on a global scale (Wania 2003). While research in this area has the ability to advance understanding in specific EC profiles and potentially predict the subsequent interactions of ECs within humans, there is a distinct need for a sentinel that closely shares our environment. It is for these reasons that we propose the dog as a sentinel species for better assessing human exposure to ECs.

\section{Geographical differences in chemical exposure}

As discussed, EC concentrations present within the environment fluctuate dependening on the geographical location, level of industrialisation, and population density. Given the contribution of industry to pollution, distinct regional variation in reproductive perturbations are reported, with higher incident rates in industrialised areas (Lin et al. 2017). Sperm samples collected from sub-fertile men in Middle Eastern and North-African regions have been reported to have lower sperm motility and morphology, alongside increased DNA damage (Elbardisi et al. 2018). In the Western world, a temporal decline in sperm quality includes North America, Europe, Australia, and New Zealand (Levine et al. 2017). In the same meta-analysis, no such trends were found in South America, Asia, and Africa. Reports had previously shown higher semen quality and a lower incidence of TCa in Finland, compared to other neighbouring countries such as Denmark (Znaor et al. 2014, Virtanen \& Toppari 2015). More recent studies now indicate that the incidence of TCa in Finland is increasing and that sperm quality is converging to the lower quality levels of Danish men (Rodprasert et al. 2019). By contrast sperm quality and TCa rates in Denmark have remained relatively stable (Priskorn et al. 2018). While geographical variations in sperm quality and TCa have been reported, data demonstrating a causal relationship with ECs are contentious (Foster et al. 2008). In this regard, the dog constitutes an appropriate sentinel model for monitoring geographical differences in seminal or testicular EC concentrations. Figure 2 illustrates that, in the dog, the testicular chemical profiles vary across different areas of the United Kingdom.

Factors influencing tissue profiles of chemicals include diet, obesity, environment, and even genetics. Increased numbers of Westernised fast food chains in these areas have led to a diet consisting of products higher in fatty foods and animal products (Elbardisi et al. 2018). Since persistent organic pollutants are lipophilic, it follows that diet may be a key source of exposure and that this, in turn, may impact on reproductive health (Pratt et al. 2012). Since the number of studies carried out in more remote areas is limited, it remains uncertain

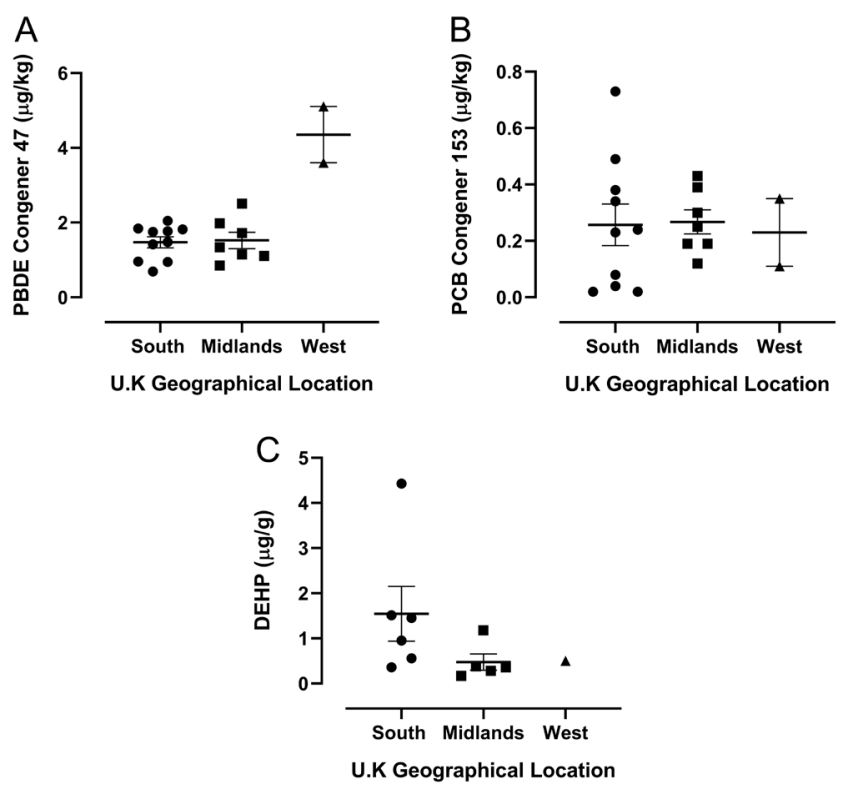

Figure 2 Geographical variation of dog testicular ECs across three regions of the United Kingdom. As shown, PBDE47, a flame retardant, was greater in samples from West England (A). PCB-153 was consistently expressed across England, even though this chemical was banned from the 1970s (B). Finally, DEHP was observed consistently in the majority of samples, other than at a greater concentration in a testicular sample from South of England (C). Data obtained as part of the data published in Lea et al. (2016b). Scientific report articles are published under a CC BY license allowing for maximum dissemination where users are free to adapt data. Error bars represent \pm 1 S.E.M. 
if fertility related perturbations are a primary problem of the industrialised world.

\section{Chemical profiling of reproductive tissues and fluids}

Returning to the dog sentinel, the availability of tissue from neutering procedures provides an opportunity to determine the profile of chemicals in testis and ovary. A total of 12 chemicals across three chemical types have been detected in both testis and ovary (Lea et al. 2016b, M.E. Van der Mescht, unpublished observation). These comprise PCBs, PBDEs, and the phthalate DEHP. These chemical types have also been detected in the dog ejaculate and from the limited studies carried out in the human. Such chemicals are likely reflective of what is present in the human. Since the basis of the sentinel paradigm is that ECs have similar effects in both species, two chemicals predominant in testis and seminal fluid, DEHP and PCB153, have been shown to have similar effects on dog and human sperm (Sumner et al. 2019). Gonad-relevant concentrations of these chemicals reduced sperm motility and increased DNA fragmentation in both species. This work demonstrates that the development of this research field could be achieved by integrating the use of a sentinel model in combination with in vitro experiments.

\section{Real-life exposure to chemical mixtures}

Real-life exposure to chemical contaminants constitutes exposure to complex mixtures of chemicals, which inevitably interact, thus influencing the overall biological or toxicological effect. Since the 1950s, it is estimated that more than 140,000 new chemicals have been produced and many of these are released into the air, sea, and soil (Landrigan 2017). Geographic variability will inevitably reflect different degrees of regional industrial activity. Since many chemicals are non-biodegradable and exhibit bioaccumulation and bio-magnification, this constitutes a concern of global magnitude. For these reasons, determining biological responses to real-life mixtures of chemicals presents a challenge to the establishment of a link between environmental contaminants and altered fertility or reproductive function.

Responses to chemicals may be dependent on whether chemicals in a mixture, as well as their respective metabolites, share similar or differing modes of action (Chen et al. 2019). Exposure to multiple ECs is reported to have a greater adverse effect compared to exposure to a single contaminant (Woodruff et al. 2011). Some in vitro studies have utilised commercially available mixtures of chemicals in toxicological in vivo studies. For example, in the mouse, the 50-day administration of a commercial mixture of PCBs (Aroclor 1254) by oral lavage every 3 days induced a significant decrease in testicular weight and increased degenerative testicular alterations.
Interestingly no changes were seen at lower doses $(0.5-$ $50 \mu \mathrm{g} / \mathrm{kg}$ ) (Cai et al. 2011). Environmental chemicals have been shown to mimic hormones such as prostaglandin and progesterone to activate CatSper channels invoking a $\mathrm{Ca}^{2+}$ ion increase. In particular, a metabolite of the pesticide Dichlorodiphenyltrichloroethane (DDT) has been reported to activate CatSper channels on sperm membranes (Schiffer et al. 2014), inducing hyperactivation of sperm. While this report demonstrates a potential mechanism of action for ECs to influence sperm quality, not all chemicals investigated invoked effects in this manner. It has been suggested that the observed chemical effects might be specific to human sperm. Some ECs that induced an influx of $\mathrm{Ca}^{2+}$ ions in human sperm had no effect in a mouse model (Schiffer et al. 2014). In combination, the ECs assessed by Schiffer and colleagues on human sperm evoked greater $\mathrm{Ca}^{2+}$ ion responses like that of progesterone in vivo (Diamanti-Kandarakis et al. 2009). The determination of EC mechanism of action is difficult due to the lack of an appropriate animal model or sentinel.

One approach, more meaningful from a biological perspective, is to use chemical mixtures relevant to everyday exposure to see if chemicals act in synergistic or additive manners. In this regard, the dog has been used to evaluate chemical mixture effects administered in a diet composed of minke whale blubber, contaminated with a cocktail of bio-accumulated chemicals. The feeding of blubber to male sled dog pups elicited direct and transgenerational effects, resulting in significantly reduced testes weight. In addition, the offspring of mothers fed that a total of $20 \mathrm{~kg}$ of blubber from 2 months postpartum to time of weaning had reduced testes weight and reduced IgG antibody concentration in blood (Kirkegaard et al. 2010, Sonne et al. 2010, 2017). These effects correlated with contaminant concentrations.

In addition to the dog, the exposure of pregnant ewes to mixtures of chemicals contained within a sewage sludge derived fertiliser (bio-solids) is widely considered as a real-life model of human exposure to chemical mixtures. A wide range of reproductive and other biological effects have been reported in developing foetuses, in addition to the offspring of mothers exposed during pregnancy. These include effects on the foetal testis, ovary, hypothalamus, and pituitary (Paul et al. 2005, Bellingham et al. 2009, Fowler et al. 2009, Lea et al. 2016a).

\section{Timing of exposure}

Exposure to chemicals is likely to occur throughout an individual's life, beginning in utero, continuing postpartum, throughout adolescence, adulthood, and gametogenesis (Fig. 3). The intrauterine environment is where the foetus is most susceptible to the exposure of endocrine disruptive ECs, due to an endocrine mediated period of growth and development (Kot et al. 2019). 


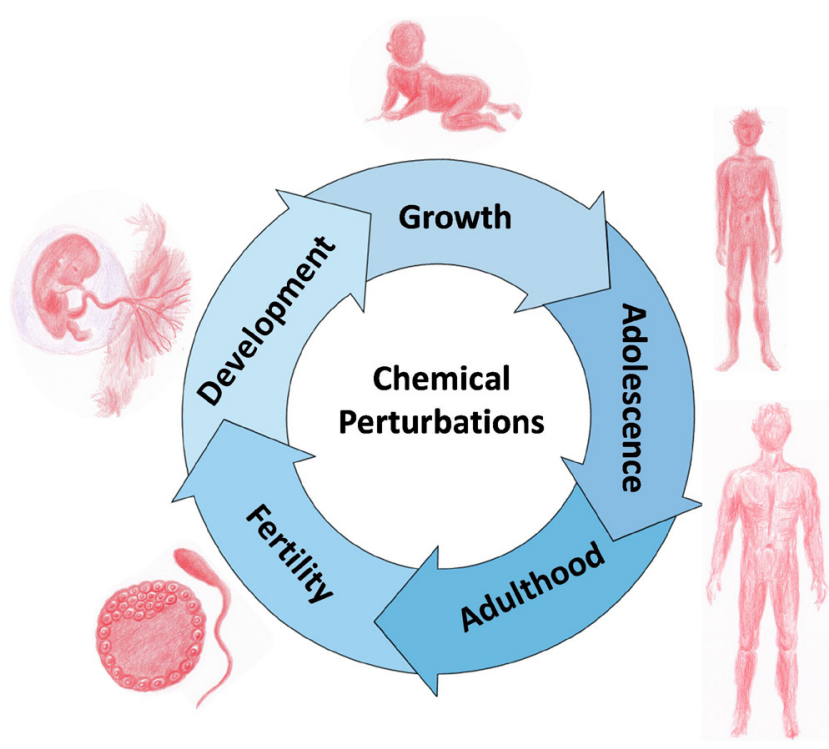

Figure 3 Exposure to chemicals can occur throughout all points in life. Each point of exposure can have a significant impact on developmental processes further in life.

The placenta is an interface at which substrate transport between mother and foetus is mediated, although some ECs have the ability to cross the placental barrier through active transplacental transfer or passive diffusion, depending on their chemical composition (Bommarito et al. 2017, Cabrera-Rodríguez et al. 2019). A recent report measuring the concentrations of trace elements and heavy metal ions found higher concentrations of lead $(\mathrm{Pb})$ in the foetal membrane and umbilical cord than in the placenta (Kot et al. 2019). This is suggestive of an accumulative nature of $\mathrm{Pb}$ and demonstrates the ability of $\mathrm{Pb}$, and other chemicals, to cross the placental barrier. Mechanisms underlying this passage, however, remain unidentified (Bommarito et al. 2017). In mice, the exposure to particulate air pollution from industrialised areas during pregnancy has been shown to induce morphological changes to the placenta (Veras et al. 2008). Changes to the integrity of the placenta could lead to a higher rate of chemical diffusion from mother to foetus, although this remains speculative at this time.

Although susceptibility to the adverse effects of ECs remains high in utero, new-borns are still at risk of endocrinological alterations through EC exposure (Wineland et al. 2019). In humans, mini-puberty occurs 1 to 12 weeks postpartum and incorporates a hormonal surge, inducing gonocyte development (Hadziselimovic et al. 2005). Exposure to ECs with endocrine disrupting properties during this time, such as via fatty breast milk, could have additional adverse effects on sexual development and maturation (Pajewska-Szmyt et al. 2019).

Breast milk is suggested as a main EC exposure route to new-borns (reviewed in Pajewska-Szmyt et al. 2019). Due to the lipophilic properties of some ECs including PCBs, Polychlorinated dibenzo-dioxins (PCDDs), and polychlorinated dibenzo-furans (PCDFs), primary deposition occurs in lipid droplets in adipose tissue, including in mammary tissue (Lee et al. 2017). During milk production, free fatty acids and lipoprotein stores are utilised, along with the release of ECs that have accumulated there (Pratt et al. 2012). Despite the lower affinity of chemicals such as BPA and other bisphenol analogues to adipose tissue, concentrations are detected in breast milk samples (Deceuninck et al. 2015). Detectable concentrations in breast milk have decreased following more stringent regulations of chemical usage (Pratt et al. 2012, Fång et al. 2013). Geographical variation is also present within breast milk samples where significant differences in POP congener type and concentration have been reported evident between countries (Antignac et al. 2016). Ingestion of chemicals by breastfed infants during mini-puberty could induce adverse effects on endocrinology and genitourinary development, having both immediate and chronic effects.

ECs are reported to adversely affect reproduction through endocrinological interactions, compromising gametogenesis (Daoud et al. 2017, lanos et al. 2018). It has also been suggested that EC exposure may, in some cases, manifest long after initial exposure due to epigenetic modifications originating from exposure at the critical window of genitourinary development in the foetus and new-born (Thankamony et al. 2016, Bommarito et al. 2017). By having the potential to interact with DNA transcription, and more specifically the molecular intricacies involved in gametogenesis, adverse effects will be present throughout an individual's life, with potential multi- and even transgenerational effects. Consequently, EC-induced adverse trends in semen quality and male fertility, as highlighted previously, could result from a combination of epigenetic modifications originating from early life exposure, cumulative concentrations of high lipophilic substances, and acute exposure to chemicals at the point of spermatogenesis, although this is only speculative.

A clear difference between the dog and human is the period of exposure due to differences in longevity. Although this may contribute to the noise observed in the human data, chemical effects are also influenced by diet, adiposity, the physico-chemical properties of the contaminants, mixture effects, metabolism, and possibly other factors that are less understood. It is therefore noteworthy that despite these many complex influences, the parallel between-species trends in reproductive function remain.

\section{Female reproductive development and function}

Historically, concerns over declining trends in male reproductive health have preceded those in the female 
and this purely reflects the relative ease of empirical study in the male. Since there are similarities in the early ontogeny of the developing male and female reproductive tracts, it has been suggested that early developmental perturbations in the female may manifest as impaired fecundity and/or altered reproductive function in later life (Buck-Louis et al. 2011). A key reproductive process that has particular sensitivity to environmental change is folliculogenesis. In the human, this highly regulated process that follows meiotic arrest of the oocyte occurs in utero, and the number of oocytes that determine female reproductive lifespan is set prior to birth. In contrast, a majority of follicle development in the dog and mouse occurs after birth, thus providing experimental access to the very earliest stages of development that are difficult to access in the human (Reynaud et al. 2012, Sarraj \& Drummond 2012).

In the human, the dysregulation of foetal ovarian development due to maternal smoking has been linked with early menopause (Tawfik et al. 2015) and there is increasing evidence of a link between premature ovarian insufficiency and exposure to environmental toxicants (reviewed in Vabre et al. 2017). In addition, widespread environmental pollutants, such as Bisphenol $\mathrm{A}$, have been reported as potential contributors to the pathogenesis of polycystic ovarian syndrome (PCOS) (Palioura \& Diamanti-Kandarakis 2015, Hu et al. 2018, Soave et al. 2020). These observations provide support for the concept of 'ovarian dysgenesis syndrome (ODS)' with additional linkages to fertility, ovarian cancer, and PCOS.

In the dog, although there is little evidence of an environmental impact on female fertility, easy access to ovaries removed at spaying does provide a means of assessing chemical contaminants directly in the gonad. In this regard, our own studies have shown that known environmental toxicants are present in the dog ovary, in some cases at higher concentrations than detected in the testis. Similar contaminants have also been detected in milk from lactating bitches (Fig. 4). Furthermore, contaminants comprising PCB congeners, PBDE congeners, and plastic-derived phthalates have been detected in commercial dog food (Lea et al. 2016b).

This raises the possibility that the perturbation of female reproductive development may occur through exposure to contaminants in the diet delivered in milk to the pups and/or via food to the mature bitch. As alluded to earlier, the partitioning of maternal lipophilic chemicals into her own high fat content milk provides a natural mechanism by which her chemicals in adipose tissue are off-loaded (Lehmann et al. 2015). The problem is that the primary source of nutrition for the neonate also becomes a source of exposure to the 'maternal legacy' of lipophilic chemical contaminants. For example, in the polar bear, PCB concentrations in the suckling cubs are higher than in the adults and the concentration found in the milk exceeds maternal dietary intake (Polischuk
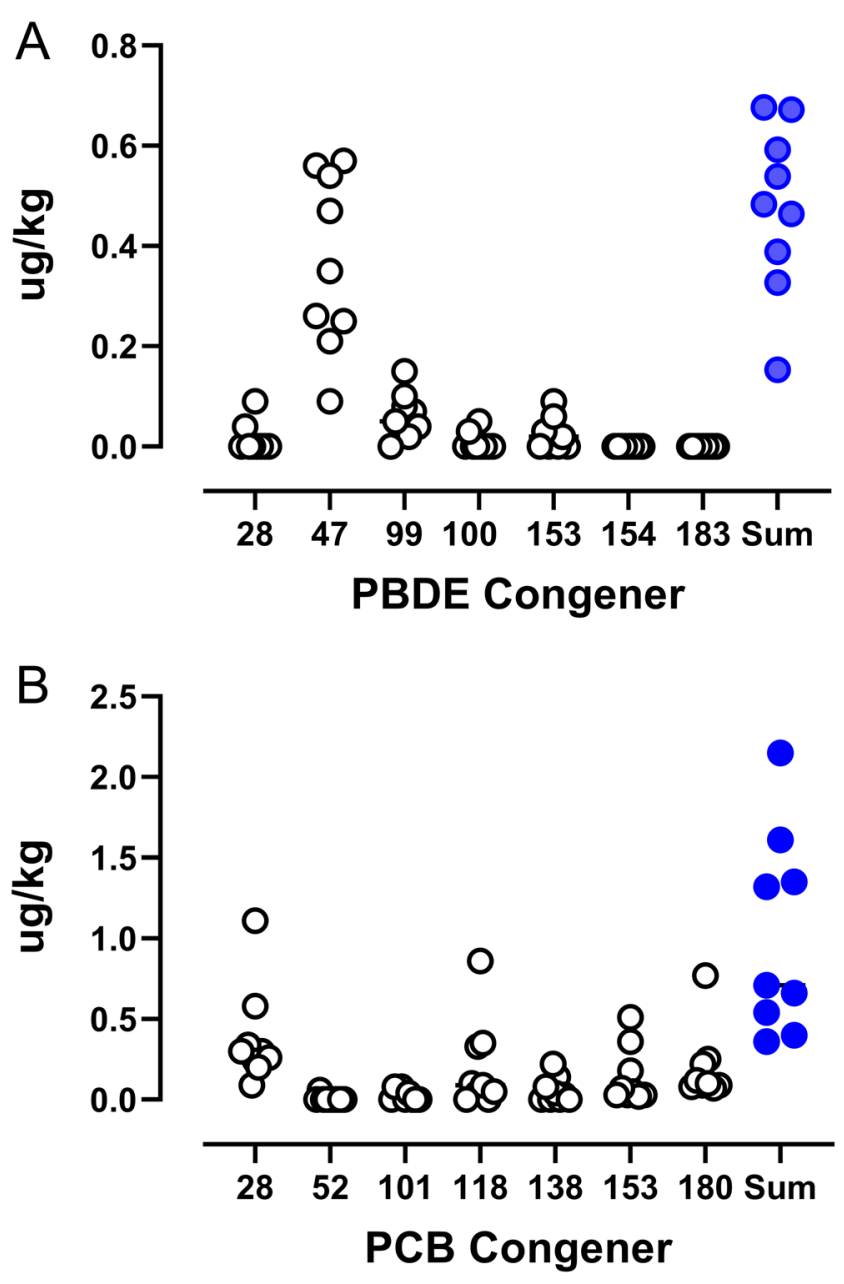

Figure 4 Contaminants detected in the milk from lactating bitches. While all chemicals present are of concern, PBDE 47 (A) is the predominant flame retardent congener. Each value represents a different analysed sample.

et al. 2002, Bytingsvik et al. 2012, Sonne et al. 2020). In the killer whale, greater concentrations of ECs have been found within the calves of lactating females, indicative of transfer from mother to offspring (Haraguchi et al. 2009). Our data showing that both PCB and PBDE congeners are detectable in the milk of whelping bitches supports this concept and these same chemical types have been detected in human milk (Needham et al. 2011, Garí et al. 2019, Pajewska-Szmyt et al. 2019).

With regard to maternal environment, it has been reported that litters of Arctic maternal sled dogs fed seal blubber as a source of environmental toxicants exhibit a skewed sex ratio in favour of females (Sonne et al. 2010). In a separate study, we have reported that pups generated in a breeding programme of assistance dogs also exhibit a temporal trend towards an altered sex ratio in favour of females. Since stud dogs from the same programme exhibit a temporal decline in semen quality that is thought to reflect exposure to chemical 
contaminants, it is possible that the feminisation of the litters may be similarly mediated (Lea et al. 2016b). Although direct chemical effects on the dog ovary have not been determined, chemicals detected in the ovary do appear to perturb early follicle development in a postnatal mouse ovary explant culture model in vitro (M.E. Van der Mescht, unpublished observation). Furthermore, in the sheep bio-solids model described previously, late gestation female lambs exposed to chemical mixtures via the mother exhibit a dysregulation in early stage follicle (primordial/transitional) development (Lea et al. 2016a).

\section{Conclusion and future remarks}

Environmental pollution remains a critical issue of global concern. There is now an overwhelming body of evidence to suggest that both male and female reproductive health is being adversely affected through exposure to mixtures of environmental contaminants. Understanding the mechanisms that underlie these effects is fraught with complexity, particularly in terms of selecting the appropriate tools to investigate environmentally relevant 'chemical cocktail' effects on the human. An invaluable experimental strategy is to identify a species in which environmental chemical exposures induce biological effects which approximate those reported in the human. In this regard, the domestic dog that shares our everyday household environment constitutes a valuable species for evaluating such effects on human reproductive health. We postulate therefore that, in combination with in vivo models, such as bio-solid exposed sheep, in vitro rodent studies, and human biomonitoring, the sentinel household dog provides an invaluable contribution to our understanding of toxicant effects on human male and female reproductive well-being.

\section{Declaration of interest}

The authors declare that there is no conflict of interest that could be perceived as prejudicing the impartiality of this review.

\section{Funding}

This research did not receive any specific grant from any funding agency in the public, commercial, or not-for-profit sector.

\section{Acknowledgements}

Authors would like to thank Silvana Robinson for her artistic contribution to figure 3 .

\section{Author contribution statement}

R G L conceived and designed the review article. R N S, IT H, and R G L contributed equally to the writing of this manuscript.
R N S and R G L created the figures for the manuscript. MV D $M, A B$, and G C W E provided information, data, and in-depth comments that developed this review. R N S, I T H, and R G L edited the manuscript for grammar and content.

\section{References}

Alava JJ \& Gobas FAPC 2016 Modeling 137Cs bioaccumulation in the salmon-resident killer whale food web of the northeastern Pacific following the Fukushima Nuclear Accident. Science of the Total Environment 544 56-67. (https://doi.org/10.1016/j.scitotenv.2015.11.097)

Antignac JP, Main KM, Virtanen HE, Boquien CY, Marchand P, Venisseau A, Guiffard I, Bichon E, Wohlfahrt-Veje C, Legrand A et al. 2016 Countryspecific chemical signatures of persistent organic pollutants (POPs) in breast milk of French, Danish and Finnish women. Environmental Pollution 218 728-738. (https://doi.org/10.1016/j.envpol.2016.07.069)

Basu N, Scheuhammer AM, Bursian SJ, Elliott J, Rouvinen-Watt K \& Chan HM 2007 Mink as a sentinel species in environmental health. Environmental Research 103 130-144. (https://doi.org/10.1016/j. envres.2006.04.005)

Bellingham M, Fowler PA, Amezaga MR, Rhind SM, Cotinot C, MandonPepin B, Sharpe RM \& Evans NP 2009 Exposure to a complex cocktail of environmental endocrine-disrupting compounds disturbs the kisspeptin/GPR54 system in ovine hypothalamus and pituitary gland. Environmental Health Perspectives 117 1556-1562. (https://doi. org/10.1289/ehp.0900699)

Bommarito PA, Martin E \& Fry RC 2017 Effects of prenatal exposure to endocrine disruptors and toxic metals on the fetal epigenome. Epigenomics 9 333-350. (https://doi.org/10.2217/epi-2016-0112)

Borch-Johnsen K 2007 The metabolic syndrome in a global perspective. The public health impact - secondary publication. Danish Medical Bulletin 54 157-159.

Bossart GD 2006 Marine mammals as sentinel species for oceans and human health. Oceanography 19 134-137. (https://doi.org/10.5670/ oceanog.2006.77)

Bowser NH \& Anderson NE 2018 Dogs (Canis familiaris) as sentinels for human infectious disease and application to Canadian populations: a systematic review. Veterinary sciences 5 83. (https://doi.org/10.3390/ vetsci5040083)

Buck-Louis GM, Cooney MA \& Peterson CM 2011 The ovarian dysgenesis syndrome. Journal of Developmental Origins of Health and Disease 2 25-35. (https://doi.org/10.1017/S2040174410000693)

Burton C 2014 Risking life and wing: Victorian and Edwardian conceptions of coal-mine canaries. Victorian Review 40 143-159. (https://doi. org/10.1353/vcr.2014.0029)

Bytingsvik J, Lie E, Aars J, Derocher AE, Wiig Ø \& Jenssen BM 2012 PCbs and $\mathrm{OH}-\mathrm{PCBs}$ in polar bear mother-cub pairs: a comparative study based on plasma levels in 1998 and 2008. Science of the Total Environment 417-418 117-128. (https://doi.org/10.1016/j.scitotenv.2011.12.033)

Cabrera-Rodríguez R, Luzardo OP, Almeida-González M, Boada LD, Zumbado $M$, Acosta-Dacal A, Rial-Berriel C \& HenríquezHernández LA 2019 Association between prenatal exposure to multiple persistent organic pollutants (POPs) and growth indicators in newborns. Environmental Research 171 285-292. (https://doi.org/10.1016/j. envres.2018.12.064)

Cai J, Wang C, Wu T, Moreno JML, Zhong Y, Huang X, Chen Y \& Zuo Z 2011 Disruption of spermatogenesis and differential regulation of testicular estrogen receptor expression in mice after polychlorinated biphenyl exposure. Toxicology 287 21-28. (https://doi.org/10.1016/j. tox.2011.05.010)

Carlsen E, Giwercman A, Keiding N \& Skakkebaek NE 1992 Evidence for decreasing quality of semen during past 50 years. BMJ 305 609-613. (https://doi.org/10.1136/bmj.305.6854.609)

Chang S, Nazem T, Gounko D, Lee J, Bar-Chama N, Shamonki J, Antonelli C \& Copperman A 2018 Eleven year longitudinal study of US sperm donors demonstrates declining sperm count and motility. Fertility and Sterility 110 e54-e55. (https://doi.org/10.1016/j.fertnstert.2018.07.170)

Chen L, Luo K, Etzel R, Zhang X, Tian Y \& Zhang J 2019 Co-exposure to environmental endocrine disruptors in the US population. Environmental Science and Pollution Research International 26 7665-7676. (https://doi. org/10.1007/s11356-018-04105-x) 
Daoud S, Sellami A, Bouassida M, Kebaili S, Ammar Keskes L, Rebai T \& Chakroun Feki N 2017 Routine assessment of occupational exposure and its relation to semen quality in infertile men: a cross-sectional study. Turkish Journal of Medical Sciences 47 902-907. (https://doi. org/10.3906/sag-1605-47)

Deceuninck Y, Bichon E, Marchand P, Boquien CY, Legrand A, Boscher C, Antignac JP \& Le Bizec B 2015 Determination of bisphenol A and related substitutes/analogues in human breast milk using gas chromatographytandem mass spectrometry. Analytical and Bioanalytical Chemistry $\mathbf{4 0 7}$ 2485-2497. (https://doi.org/10.1007/s00216-015-8469-9)

Desforges JP, Hall A, McConnell B, Rosing-Asvid A, Barber JL, Brownlow A, De Guise S, Eulaers I, Jepson PD, Letcher RJ et al. 2018 Predicting global killer whale population collapse from PCB pollution. Science 361 1373-1376. (https://doi.org/10.1126/science.aat1953)

Diamanti-Kandarakis E, Bourguignon JP, Giudice LC, Hauser R, Prins GS, Soto AM, Zoeller RT \& Gore AC 2009 Endocrine-disrupting chemicals: an Endocrine Society scientific statement. Endocrine Reviews $\mathbf{3 0}$ 293-342. (https://doi.org/10.1210/er.2009-0002)

Dusanov S, Ruzzin J, Kiviranta H, Klemsdal TO, Retterstøl L, Rantakokko P, Airaksinen R, Djurovic S \& Tonstad S 2018 Associations between persistent organic pollutants and metabolic syndrome in morbidly obese individuals. Nutrition, Metabolism, and Cardiovascular Diseases 28 735-742. (https://doi.org/10.1016/j.numecd.2018.03.004)

Dye JA, Venier M, Zhu L, Ward CR, Hites RA \& Birnbaum LS 2007 Elevated PBDE levels in pet cats: sentinels for humans? Environmental Science and Technology 41 6350-6356. (https://doi.org/10.1021/es0708159)

Elbardisi H, Majzoub A, Al Said S, Al Rumaihi K, El Ansari W, Alattar A \& Arafa M 2018 Geographical differences in semen characteristics of 13892 infertile men. Arab Journal of Urology 16 3-9. (https://doi. org/10.1016/j.aju.2017.11.018)

Ellulu MS \& Jalambo MO 2017 Gene-environment interaction: the causes of high obesity incidence. Kathmandu University Medical Journal 15 91-93. (https://doi.org/10.15761/MCA.1000104)

England GCW, Phillips L \& Freeman SL 2010 Heritability of semen characteristics in dogs. Theriogenology 74 1136-1140. (https://doi. org/10.1016/j.theriogenology.2010.05.012)

Fång J, Nyberg E, Bignert A \& Bergman A 2013 Temporal trends of polychlorinated dibenzo-p-dioxins and dibenzofurans and dioxin-like polychlorinated biphenyls in mothers' milk from Sweden, 1972-2011. Environment International 60 224-231. (https://doi.org/10.1016/j. envint.2013.08.019)

Foster WG, Neal MS, Han MS \& Dominguez MM 2008 Environmental contaminants and human infertility: hypothesis or cause for concern? Journal of Toxicology and Environmental Health: Part B, Critical Reviews 11 162-176. (https://doi.org/10.1080/10937400701873274)

Fowler PA, Bhattacharya S, Gromoll J, Monteiro A \& O'Shaughnessy PJ 2009 Maternal smoking and developmental changes in luteinizing hormone (LH) and the $\mathrm{LH}$ receptor in the fetal testis. Journal of Clinical Endocrinology and Metabolism 94 4688-4695. (https://doi.org/10.1210/ jc.2009-0994)

Garí M, Grimalt JO, Vizcaino E, Tardón A \& Fernández-Somoano A 2019 Mother-child transfer rates of organohalogen compounds up to four years of age. Environment International 133 105241. (https://doi. org/10.1016/j.envint.2019.105241)

Ghazarian AA, Rusner C, Trabert B, Braunlin M, McGlynn KA \& Stang A 2018 Testicular cancer among US men aged 50 years and older. Cancer Epidemiology 55 68-72. (https://doi.org/10.1016/j.canep.2018.05.007)

Grieco V, Riccardi E, Greppi GF, Teruzzi F, lermanò V \& Finazzi M 2008a Canine testicular tumours: a study on 232 dogs. Journal of Comparative Pathology 138 86-89. (https://doi.org/10.1016/j.jcpa.2007.11.002)

Grieco V, Riccardi E, Veronesi MC, Giudice C \& Finazzi M 2008b Evidence of testicular dysgenesis syndrome in the dog. Theriogenology 70 53-60. (https://doi.org/10.1016/j.theriogenology.2008.02.009)

Hadziselimovic F, Zivkovic D, Bica DTG, Emmons LR 2005 The importance of mini-puberty for fertility in cryptorchidism. Journal of Urology 174 1536-1539; discussion 1538. (https://doi.org/10.1097/01. ju.0000181506.97839.b0)

Haraguchi K, Hisamichi Y \& Endo T 2006 Bioaccumulation of naturally occurring mixed halogenated dimethylbipyrroles in whale and dolphin products on the Japanese market. Archives of Environmental Contamination and Toxicology 51 135-141. (https://doi.org/10.1007/ s00244-005-1140-2)
Haraguchi K, Hisamichi Y \& Endo T 2009 Accumulation and motherto-calf transfer of anthropogenic and natural organohalogens in killer whales (Orcinus orca) stranded on the Pacific coast of Japan. Science of the Total Environment 407 2853-2859. (https://doi.org/10.1016/j. scitotenv.2009.01.003)

Harley JR, Bammler TK, Farin FM, Beyer RP, Kavanagh TJ, Dunlap KL, Knott KK, Ylitalo GM \& O'Hara TM 2016 Using domestic and freeranging Arctic canid models for environmental molecular toxicology research. Environmental Science and Technology 50 1990-1999. (https://doi.org/10.1021/acs.est.5b04396)

Hermansson U \& Forsberg CL 2006 Freezing of stored, chilled dog spermatozoa. Theriogenology 65 584-593. (https://doi.org/10.1016/j. theriogenology.2005.06.004)

Hu Y, Wen S, Yuan D, Peng L, Zeng R, Yang Z, Liu Q, Xu L \& Kang D 2018 The association between the environmental endocrine disruptor bisphenol A and polycystic ovary syndrome: a systematic review and meta-analysis. Gynecological Endocrinology 34 370-377. (https://doi.or g/10.1080/09513590.2017.1405931)

Ianos O, Sari-Minodier I, Villes V, Lehucher-Michel MP, Loundou A \& Perrin J 2018 Meta-analysis reveals the association between male occupational exposure to solvents and impairment of semen parameters. Journal of Occupational and Environmental Medicine 60 e533-e542. (https://doi.org/10.1097/JOM.0000000000001422)

Jamieson AJ, Malkocs T, Piertney SB, Fujii T \& Zhang Z 2017 Bioaccumulation of persistent organic pollutants in the deepest ocean fauna. Nature Ecology and Evolution 1 51. (https://doi.org/10.1038/ s41559-016-0051)

Jeon JY, Ha KH \& Kim DJ 2015 New risk factors for obesity and diabetes: environmental chemicals. Journal of Diabetes Investigation 6 109-111. (https://doi.org/10.1111/jdi.12318)

Jeong Y, Lee Y, Park KJ, An YR \& Moon HB 2019 Accumulation and time trends (2003-2015) of persistent organic pollutants (POPs) in blubber of finless porpoises (Neophocaena asiaeorientalis) from Korean coastal waters. Journal of Hazardous Materials 385 121598. (https://doi. org/10.1016/j.jhazmat.2019.121598)

Jepson PD, Deaville R, Barber JL, Aguilar À, Borrell A, Murphy S, Barry J, Brownlow A, Barnett J, Berrow S et al. 2016 PCB pollution continues to impact populations of orcas and other dolphins in European waters. Scientific Reports 6 18573. (https://doi.org/10.1038/srep18573)

Kaya C, Aykaç A, Kaya Y \& Taş M 2020 The effect of modifiable lifestyle factors on semen quality. Revista Internacional de Andrología. (available at: https://www.ncbi.nlm.nih.gov/pubmed/31953028). Accessed on 01/03/2020. (https://doi.org/10.1016/j.androl.2019.09.001)

Kirkegaard M, Sonne C, Dietz R, Jenssen BM, Leifsson PS, Jensen J-EB \& Letcher RJ 2010 Testosterone concentrations and male genital organ morphology in Greenland sledge dogs (Canis familiaris) dietary exposed to organohalogen contaminants. Toxicological and Environmental Chemistry 92 955-967. (https://doi.org/10.1080/02772240903143836)

Kot K, Kosik-Bogacka D, tanocha-Arendarczyk N, Malinowski W, Szymański S, Mularczyk M, Tomska N \& Rotter I 2019 Interactions between 14 elements in the human placenta, fetal membrane and umbilical cord. International Journal of Environmental Research and Public Health 16 1-13. (https://doi.org/10.3390/ijerph16091615)

Kurt-Karakus PB, Muir DCG, de Jourdan B, Teixeira C, Epp Martindale J, Embers H, Wang X, Keir M \& Backus S 2019 Bioaccumulation of selected halogenated organic flame retardants in Lake Ontario. Environmental Toxicology and Chemistry 38 1198-1210. (https://doi.org/10.1002/ etc.4413)

Landrigan PJ 2017 Air pollution and health. In The Lancet Public Health. The 679 Author(s). Published by Elsevier Ltd. This is an Open Access article under the 680 CC BY license, 2(1), pp. e4-e5.

Landrigan PJ, Fuller R, Acosta NJR, Adeyi O, Arnold R, Basu N, Baldé AB, Bertollini R, Bose-O'Reilly S, Boufford Jl et al. 2018 The Lancet Commission on pollution and health. Lancet 391 462-512. (https://doi. org/10.1016/S0140-6736(17)32345-0)

Lea RG, Amezaga MR, Loup B, Mandon-Pépin B, Stefansdottir A, Filis P, Kyle C, Zhang Z, Allen C, Purdie L et al. 2016a The fetal ovary exhibits temporal sensitivity to a 'real-life' mixture of environmental chemicals. Scientific Reports 6 1-13. (https://doi.org/10.1038/srep22279)

Lea RG, Byers AS, Sumner RN, Rhind SM, Zhang Z, Freeman SL, Moxon R, Richardson HM, Green M, Craigon J et al. 2016b Environmental chemicals impact dog semen quality in vitro and may be associated 
with a temporal decline in sperm motility and increased cryptorchidism. Scientific Reports 6 31281. (https://doi.org/10.1038/srep31281)

Lee YM, Kim KS, Jacobs DR \& Lee DH 2017 Persistent organic pollutants in adipose tissue should be considered in obesity research. Obesity Reviews 18 129-139. (https://doi.org/10.1111/obr.12481)

Lehmann GH, Verner MA, Luukinen B, Henning C, Assimon SA, LaKind JS, McLanahan ED, Phillips LJ, Davis MH, Powers CM et al. 2015 Improving the risk assessment of lipophilic persistent environmental chemicals in breast milk. Critical Review in Toxicology 44 600-617. (https://doi.org/1 0.3109/10408444.2014.926306)

Lenoir A, Boulay R, Dejean A, Touchard A \& Cuvillier-Hot V 2016 Phthalate pollution in an Amazonian rainforest. Environmental Science and Pollution Research International 23 16865-16872. (https://doi. org/10.1007/s11356-016-7141-z)

Levine H, Jørgensen N, Martino-Andrade A, Mendiola J, Weksler-Derri D, Mindlis I, Pinotti R \& Swan SH 2017 Temporal trends in sperm count: a systematic review and meta-regression analysis. Human Reproduction Update 23 646-659. (https://doi.org/10.1093/humupd/dmx022)

Lin Z, Wang L, Jia Y, Zhang Y, Dong Q \& Huang C 2017 A study on environmental bisphenol A pollution in plastics industry areas, water air, and soil pollution. Water, Air, and Soil Pollution 228 98. (https://doi. org/10.1007/s11270-017-3277-9)

López-Alonso M, Miranda M, García-Partida P, Cantero F, Hernández J \& Benedito JL 2007 Use of dogs as indicators of metal exposure in rural and urban habitats in NW Spain. Science of the Total Environment 372 668-675. (https://doi.org/10.1016/j.scitotenv.2006.10.003)

Majdič G 2010 Endocrine disrupting chemicals and domestic animals. Slovenian Veterinary Research 47 5-11.

Mínguez-Alarcón L, Gaskins AJ, Chiu YH, Messerlian C, Williams PL, Ford JB, Souter I, Hauser R \& Chavarro JE 2018 Type of underwear worn and markers of testicular function among men attending a fertility center. Human Reproduction 33 1749-1756. (https://doi.org/10.1093/ humrep/dey259)

Mitchell RT, Cowan G, Morris KD, Anderson RA, Fraser HM, Mckenzie KJ, Wallace WHB, Kelnar CJH, Saunders PTK \& Sharpe RM 2008 Germ cell differentiation in the marmoset (Callithrix jacchus) during fetal and neonatal life closely parallels that in the human. Human Reproduction 23 2755-2765. (https://doi.org/10.1093/humrep/den295)

Needham LL, Grandjean P, Heinzow B, Jørgensen PJ, Nielsen F, Patterson DG, Sjödin A, Turner WE \& Weihe P 2011 Partition of environmental chemicals between maternal and fetal blood and tissues. Environmental Science and Technology 45 1121-1126. (https://doi. org/10.1021/es1019614)

O'Brien DJ, Kaneene JB \& Poppenga RH 1993 The use of mammals as sentinels for human exposure to toxic contaminants in the environment Environmental Health Perspectives 99 351-368. (https://doi.org/10.1289/ ehp.9399351)

Pacey AA 2013 Are sperm counts declining? or did we just change our spectacles? Asian Journal of Andrology 15 187-190. (https://doi. org/10.1038/aja.2012.165)

Pajewska-Szmyt M, Sinkiewicz-Darol E \& Gadzała-Kopciuch R 2019 The impact of environmental pollution on the quality of mother's milk. Environmental Science and Pollution Research International 26 7405-7427. (https://doi.org/10.1007/s11356-019-04141-1)

Palioura E \& Diamanti-Kandarakis E 2015 Polycystic ovary syndrome (PCOS) and endocrine disrupting chemicals (EDCs). Reviews in Endocrine and Metabolic Disorders 16 365-371. (https://doi.org/10.1007/s11154016-9326-7)

Park JS, Kim J, Elghiaty A \& Ham WS 2018 Recent global trends in testicular cancer incidence and mortality. Medicine 97 e12390. (https:// doi.org/10.1097/MD.0000000000012390)

Paul C, Rhind SM, Kyle CE, Scott H, McKinnell C \& Sharpe RM 2005 Cellular and hormonal disruption of fetal testis development in sheep reared on pasture treated with sewage sludge. Environmental Health Perspectives 113 1580-1587. (https://doi.org/10.1289/ehp.8028)

Petro EML, Covaci A, Leroy JLMR, Dirtu AC, De Coen W \& Bols PEJ 2010 Occurrence of endocrine disrupting compounds in tissues and body fluids of Belgian dairy cows and its implications for the use of the cow as a model to study endocrine disruption. Science of the Total Environment 408 5423-5428. (https://doi.org/10.1016/j.scitotenv.2010.07.051)

Pishgar F, Haj-Mirzaian A, Ebrahimi H, Saeedi Moghaddam S, Mohajer B, Nowroozi MR, Ayati M, Farzadfar F, Fitzmaurice C \& Amini E 2019
Global, regional and national burden of testicular cancer, 1990-2016: results from the Global Burden of Disease Study 2016. BJU International 124 386-394. (https://doi.org/10.1111/bju.14771)

Polischuk SC, Norstrom RJ \& Ramsay MA 2002 Body burdens and tissue concentrations of organochlorines in polar bears (Ursus maritimus) vary during seasonal fasts. Environmental Pollution 118 29-39. (https://doi. org/10.1016/s0269-7491(01)00278-0)

Ponglowhapan S, Chatdarong K, Sirivaidyapong S \& Lohachit C 2006 Freezing of epididymal spermatozoa from dogs after cool storage for 2 or 4 days. Theriogenology 66 1633-1636. (https://doi.org/10.1016/j. theriogenology.2006.01.032)

Pratt IS, Anderson WA, Crowley D, Daly SF, Evans RI, Fernandes AR, Fitzgerald M, Geary MP, Keane DP, Malisch $\mathbf{R}$ et al. 2012 Polychlorinated dibenzo-p-dioxins (PCDDs), polychlorinated dibenzofurans (PCDFs) and polychlorinated biphenyls (PCBs) in breastmilk of first-time Irish mothers: impact of the 2008 dioxin incident in Ireland. Chemosphere 88 865-872. (https://doi.org/10.1016/j.chemosphere. 2012.03.095)

Priskorn L, Nordkap L, Bang AK, Krause M, Holmboe SA, Egeberg Palme DL, Winge SB, Mørup N, Carlsen E, Joensen UN et al. 2018 Average sperm count remains unchanged despite reduction in maternal smoking: results from a large cross-sectional study with annual investigations over 21 years. Human Reproduction 33 998-1008. (https://doi.org/10.1093/ humrep/dey090)

Rabinowitz PM, Scotch ML \& Conti LA 2010 Animals as sentinels: using comparative medicine to move beyond the laboratory. ILAR Journal $\mathbf{5 1}$ 262-267. (https://doi.org/10.1093/ilar.51.3.262)

Rayne S, Ikonomou MG, Ross PS, Ellis GM \& Barrett-Lennard LG 2004 PBDEs, PBBs, and PCNs in three communities of free-ranging killer whales (Orcinus orca) from the northeastern Pacific Ocean. Environmental Science and Technology 38 4293-4299. (https://doi. org/10.1021/es0495011)

Reynaud K, Fontbonne A, Saint-Dizier M, Thoumire S, Marnier C, Tahir MZ, Meylheuc T \& Chastant-Maillard S 2012 Folliculogenesis, ovulation and endocrine control of oocytes and embryos in the dog. Reproduction in Domestic Animals 47 (Supplement 6) 66-69. (https:// doi.org/10.1111/rda.12055)

Rivera OE, Varayoud J, Rodriguez HA, Mauro CE, Muaoz-de-Toro M \& Luque EH 2009221 Xenoestrogens exposure at environmentally relevant doses adversely affects ovine follicular development. Reproduction, Fertility and Development 22 268-269. (https://doi.org/10.1071/ RDv22n1Ab221)

Rodprasert W, Virtanen HE, Sadov S, Perheentupa A, Skakkebæk NE, Jørgensen N \& Toppari J 2019 An update on semen quality among young Finnish men and comparison with Danish data. Andrology 7 15-23. (https://doi.org/10.1111/andr.12550)

Rolland M, Le Moal J, Wagner V, Royère D \& De Mouzon J 2013 Decline in semen concentration and morphology in a sample of 26609 men close to general population between 1989 and 2005 in France. Human Reproduction 28 462-470. (https://doi.org/10.1093/humrep/des415)

Sarraj MA \& Drummond AE 2012 Mammalian foetal ovarian development: consequences for health and disease. Reproduction 143 151-163. (https://doi.org/10.1530/REP-11-0247)

Schiffer C, Muller A, Egeberg DL, Alvarez L, Brenker C, Rehfeld A, Frederiksen H, Waschle B, Kaupp UB, Balbach M et al. 2014 Direct action of endocrine disrupting chemicals on human sperm. EMBO Reports 15 758-765. (https://doi.org/10.15252/embr.201438869)

Schilling RJ \& Stehr-Green PA 1987 Health effects in family pets and 2,3,7,8-tcdd contamination in Missouri: a look at potential animal sentinels. Archives of Environmental Health 42 137-139. (https://doi.org /10.1080/00039896.1987.9935810)

Schilling RJ, Steele GK, Harris AE, Donahue JF \& Ing RT 1988 Canine serum levels of polychlorinated biphenyls (pcbs): a pilot study to evaluate the use of animal sentinels in environmental health. Archives of Environmental Health 43 218-221. (https://doi.org/10.1080/0003989 6.1988.9934936)

Schmidt PL 2009 Companion animals as sentinels for Public Health. Veterinary Clinics of North America: Small Animal Practice 39 241-250. (https://doi.org/10.1016/j.cvsm.2008.10.010)

Sharpe RM 2012 Sperm counts and fertility in men: A Rocky Road ahead. Science \& Society Series on Sex and Science. EMBO Reports 13 398-403. (https://doi.org/10.1038/embor.2012.50) 
Skakkebaek NE, Rajpert-De Meyts E, Buck Louis GM, Toppari J, Andersson AM, Eisenberg ML, Jensen TK, Jørgensen N, Swan SH, Sapra KJ et al. 2016 Male reproductive disorders and fertility trends: influences of environment and genetic susceptibility. Physiological Reviews 96 55-97. (https://doi.org/10.1152/physrev.00017.2015)

Soave I, Occhiali T, Assorgi C, Marci R \& Caserta D 2020 Environmental toxins exposure in PCOS women and possible ovarian neoplastic repercussion. Current Medical Research and Opinion 36 693-703. (https://doi.org/10.1080/03007995.2020.1729108)

Sonne C 2010 Health effects from long-range transported contaminants in Arctic top predators: an integrated review based on studies of polar bears and relevant model species. Environment International 36 461-491. (https://doi.org/10.1016/j.envint.2010.03.002)

Sonne C, Larsen HJS, Kirkegaard M, Letcher RJ \& Dietz R 2010 Transgenerational and neonatal humoral immune responses in West Greenland sledge dogs (Canis familiaris) exposed to organohalogenated environmental contaminants. Science of the Total Environment $\mathbf{4 0 8}$ 5801-5807. (https://doi.org/10.1016/j.scitotenv.2010.07.076)

Sonne C, Torjesen PA, Fuglei E, Muir DCG, Jenssen BM, Jørgensen EH, Dietz R \& Ahlstrøm Ø 2017 Exposure to persistent organic pollutants reduces testosterone concentrations and affects sperm viability and morphology during the mating peak period in a controlled experiment on farmed Arctic foxes (Vulpes lagopus). Environmental Science and Technology 51 4673-4680. (https://doi.org/10.1021/acs.est.7b00289)

Sonne C, Vorkamp K, Galatius A, Kyhn L, Teilmann J, Bossi R, Søndergaard J, Eulaers I, Desforges JP, Siebert U et al. 2019 Human exposure to PFOS and mercury through meat from Baltic harbour seals (Phoca vitulina). Environmental Research 175 376-383. (https://doi.org/10.1016/j. envres.2019.05.026)

Sonne C, Letcher RJ, Jenssen BM, Desforges J-P, Eulaers I, AndersenRanberg E, Gustavson K, Bossi R, Styrishave B \& Dietz R 2020 Sled dogs as sentinel species for monitoring Arctic ecosystem health. 1 1-34. In Pets as Sentinels, Forecasters and Promoters of Human Health, pp.21-45 Eds M Pastorinho \& A Sousa. Springer, Cham.

Sumner RN, Tomlinson M, Craigon J, England GCW \& Lea RG 2019 Independent and combined effects of diethylhexyl phthalate and polychlorinated biphenyl 153 on sperm quality in the human and dog. Scientific Reports 9 3409. (https://doi.org/10.1038/s41598-019-39913-9)

Swan SH, Elkin EP \& Fenster L 2000 The question of declining sperm density revisited: an analysis of 101 studies published 1934-1996. Environmental Health Perspectives 108 961-966. (https://doi. org/10.1289/ehp.00108961)

Tawfik H, Kline J, Jacobson J, Tehranifar P, Protacio A, Flom JD, Cirillo P, Cohn BA \& Terry MB 2015 Life course exposure to smoke and early menopause and menopausal transition. Menopause 22 1076-1083. (https://doi.org/10.1097/GME.0000000000000444)

Terzaghi E, Zanardini E, Morosini C, Raspa G, Borin S, Mapelli F, Vergani L \& Di Guardo A 2018 Rhizoremediation half-lives of PCbs: role of congener composition, organic carbon forms, bioavailability, microbial activity, plant species and soil conditions, on the prediction of fate and persistence in soil. Science of the Total Environment 612 544-560. (https://doi.org/10.1016/j.scitotenv.2017.08.189)

Thankamony A, Pasterski V, Ong KK, Acerini CL \& Hughes IA 2016 Anogenital distance as a marker of androgen exposure in humans. Andrology 4 616-625. (https://doi.org/10.1111/andr.12156)

Tiegs AW, Landis J, Garrido N, Scott RT \& Hotaling JM 2019 Total motile sperm count trend over time: evaluation of semen analyses From
119,972 men From subfertile couples. Urology 132 109-116. (https:// doi.org/10.1016/j.urology.2019.06.038)

Tran BC, Teil MJ, Blanchard M, Alliot F \& Chevreuil M 2015 Fate of phthalates and BPA in agricultural and non-agricultural soils of the Paris area (France). Environmental Science and Pollution Research International 22 11118-11126. (https://doi.org/10.1007/s11356-0154178-3)

Vabre P, Gatimel N, Moreau J, Gayrard V, Picard-Hagen N, Parinaud J \& Leandri RD 2017 Environmental pollutants, a possible etiology for premature ovarian insufficiency: a narrative review of animal and human data. Environmental Health 16 1-18. (https://doi.org/10.1186/s12940017-0242-4)

Van Der Schalie WH, Gardner HS, Bantle JA, De Rosa CT, Finch RA, Reif JS, Reuter RH, Backer LC, Burger J, Folmar LC et al. 1999 Animals as sentinels of human health hazards of environmental chemicals. Environmental Health Perspectives 107 309-315. (https://doi. org/10.1289/ehp.99107309)

Veras MM, Damaceno-Rodrigues NR, Caldini EG, Ribeiro AACM, Mayhew TM, Saldiva PHN \& Dolhnikoff M 2008 Particulate urban air pollution affects the functional morphology of mouse placenta. Biology of Reproduction 79 578-584. (https://doi.org/10.1095/ biolreprod.108.069591)

Virtanen HE \& Toppari J 2015 Cryptorchidism and fertility. Endocrinology and Metabolism Clinics 44 751-760. (https://doi.org/10.1016/j. ecl.2015.07.013)

Wahl RL \& Reif JS 2009 Temporal trends in bull semen quality: a comparative model for human health? Environmental Research 109 273-280. (https://doi.org/10.1016/j.envres.2008.10.012)

Wania F 2003 Assessing the potential of persistent organic chemicals for long-range transport and accumulation in polar regions. Environmental Science and Technology 37 1344-1351. (https://doi.org/10.1021/ es026019e)

Weijs L, Leusch F \& Covaci A 2019 Concentrations of legacy persistent organic pollutants and naturally produced MeO-PBDEs in dugongs (Dugong dugon) from Moreton Bay, Australia. Chemosphere 229 500-508. (https://doi.org/10.1016/j.chemosphere.2019.05.033)

Wineland RJ, Bloom MS, Cruze L, Butts CD, Wenzel AG, Unal ER, Kohno S, Willan KB, Brock JW \& Newman RB 2019 In utero effects of maternal phthalate exposure on male genital development. Prenatal Diagnosis 39 209-218. (https://doi.org/10.1002/pd.5398)

Woodruff TJ, Zota AR \& Schwartz JM 2011 Environmental chemicals in pregnant women in the united states: NHANES 2003-2004. Environmental Health Perspectives 119 878-885. (https://doi. org/10.1289/ehp.1002727)

Znaor A, Lortet-Tieulent J, Jemal A \& Bray F 2014 International variations and trends in testicular cancer incidence and mortality. European Urology: European Association of Urology 65 1095-1106. (https://doi. org/10.1016/j.eururo.2013.11.004)

Received 20 January 2020

First decision 13 February 2020

Revised manuscript received 12 March 2020

Accepted 26 March 2020 